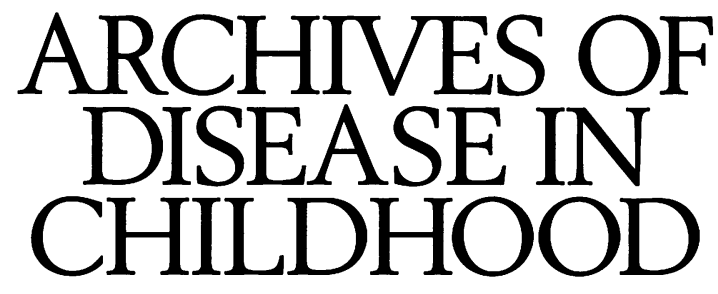

The Fournal of the British Paediatric Association

\title{
Annotations
}

\section{Insulin and insulin-like growth factors in diabetes mellitus}

The development of recombinant insulin-like growth factor-I (rhIGF-I) has provided added impetus to the exploration of the biological actions of IGF-I and its possible clinical applications. Naturally interest has focused on the growth promoting effects of IGF-I and once the recombinant peptide was shown to improve linear growth in hypophysectomised and growth hormone deficient rats, the first clinical trials were undertaken in the treatment of growth hormone insensitivity syndromes or Laron type dwarfism. However, there has also been renewed interest in the therapeutic applications of the insulin-like effects of IGF-I. ${ }^{1}$

\section{Structure of IGF-I and its receptor}

It is many years since Zapf and his colleagues first demonstrated that somatomedin C, or as it is now known IGF-I, exerted metabolic effects in vitro that closely resembled those of insulin. ${ }^{2}$ The structure of IGF-I proved to be very similar to that of insulin and there is $43 \%$ sequence homology between human proinsulin and IGF-I. As well as similarities in their molecular structures IGF-I and insulin also share receptor interactions. Insulin and IGF-I receptors are both structurally and functionally very similar, comprising two extracellular alpha subunits, which are primarily concerned with hormone binding, and two beta subunits, with transmembrane and tyrosine kinase domains, which are involved in intracellular signalling. It has been shown that both peptides may induce either metabolic or mitogenic effects through their own receptor and there has been considerable interest in how, under normal physiological conditions, insulin largely regulates intermediary metabolism whereas IGF-I is involved in the regulation of growth and development. ${ }^{3}$ The divergent actions of IGF-I and insulin may result from subtle differences in receptor structure and thus postreceptor signalling, but the other important feature which distinguishes insulin and IGF-I actions is the presence and function of the IGF binding proteins (IGF-BPs).

\section{IGF binding proteins and the regulation of IGF bioactivity}

Unlike insulin, IGF-I is produced by a wide variety of tissues and there are no tissue stores, although the liver contributes the greatest amount to circulating concentrations and IGF-I seems to be produced at a relatively constant rate of around 3-40 $\mathrm{\mu g} / \mathrm{kg} / \mathrm{day}$. IGF-I circulates in much greater concentrations than those of insulin as it is bound to a series of binding proteins of which a total of six (IGFBP1-6) have been described to date. ${ }^{4}$ The largest of these binding proteins IGFBP-3, when combined with IGF-I and an acid labile subunit produced by the liver under the control of growth hormone, provides a circulating reservoir of IGF-I which is retained in the circulation. The half life of unbound IGF-I is around 12-20 minutes whereas the half life of the ternary complex is 13-20 hours. Detailed discussion of roles of the other IGFBPs is beyond the scope of this article, but it would appear that they have roles in different tissues to facilitate the bioavailability and modulate the bioactivity of IGF-I. ${ }^{5}$

Circulating IGF-I concentrations parallel those of fasting insulin very closely during childhood and adolescence. The increases in both IGF-I and insulin concentrations during puberty have been related to changes in growth hormone secretion and sex steroid levels. ${ }^{6}$ Thus not only does growth hormone regulate concentrations of IGF-I during puberty, but it also affects fasting insulin concentrations by the induction of insulin resistance in peripheral tissues. ${ }^{7}$ Recent data have increased the complexity of these interactions for it is now known that insulin is also an important regulator of the growth hormone/IGF-I axis.

\section{Regulation of IGF-I concentrations and IGF \\ bioactivity by insulin}

There is considerable in vitro evidence that insulin enhances IGF-I production by either direct regulation of the growth hormone receptor or a permissive effect on post-receptor events. Some in vivo confirmation of these observations in humans has come from studies of the growth hormone binding protein (GHBP) which appears to be identical to the extracellular domain of the growth hormone receptor. Both insulin and nutritional status have proved to be important determinants of circulating GHBP and IGF-I concentrations. ${ }^{8}$

As well as regulating IGF-I production at the level of the growth hormone receptor, insulin also regulates IGF bioactivity through the circulating concentrations of the small molecular weight, IGF binding protein, IGFBP-1. 
IGFBP-1 is largely produced by the hepatocyte and its production is inversely regulated by insulin. ${ }^{9}$ Circulating IGFBP-1 concentrations undergo a circadian variation with peak values being observed overnight when insulin is at its lowest and in most bioassay systems IGFBP-1 is an inhibitor of IGF bioactivity.

During puberty, as fasting insulin concentrations rise, IGFBP-1 declines and it has been argued that suppression of this IGF inhibitor might be one mechanism by which insulin regulates the tempo of growth. ${ }^{10}$ The observation made by Lewitt et al, however, that the infusion of IGFBP1 leads to a prompt rise of blood glucose in experimental animals, which is reversed by rhIGF-I, ${ }^{11}$ leads to the additional intriguing hypothesis that IGFBP-I may have a role in glucose homoeostasis. Thus the high IGFBP-I concentrations overnight when insulin is low may inhibit the effects of free IGF-I on glucose homoeostasis, and the reverse may be true in the fed state.

In vitro animal studies have shown that IGF-I has effects on glucose uptake, which are distinct from those of insulin particularly in muscle where IGF-I receptors are abundant. ${ }^{12}$ These effects are reversed by IGFBP-1, and may be complementary to those of insulin. Thus variations in the concentrations of free IGF-I, brought about by changes in the IGFBPs may have important effects on glucose homoeostasis.

\section{Metabolic effects of rhIGF-I in normal subjects}

Guler et al were first to show that rhIGF-I had an acute hypoglycaemic effect in healthy human volunteers. ${ }^{13}$ However, rhIGF-I proved to be 10 times less potent in this respect than equivalent doses of insulin. Differential tissue effects between insulin and IGF-I were also observed which could be explained by differences in receptor distribution. For example, IGF-I appears to have more effect on glucose uptake by muscle than on hepatic glucose production because of the relative paucity of IGF-I receptors on the adult liver. IGF-I effects on the adipocyte are also less than those of insulin, whereas IGF-I appears to be more effective than insulin in stimulating protein synthesis. ${ }^{14}$ However, it is unclear from many of these studies whether the high doses of rhIGF-I used are exerting their effects through the IGF-I or the insulin receptor. Furthermore, many of the differential effects may result from differences in the relative suppression of endogenous insulin, glucagon, and growth hormone production. ${ }^{15}$

Preliminary studies utilising the insulin-like effects of IGF-I have been successful in severe insulin resistant states ${ }^{16}$ but have led to unacceptable side effects in patients with non-insulin dependent diabetes mellitus, probably because of the high doses used. ${ }^{17}$ Attempts to utilise the anabolic effects of rhIGF-I may be limited by the parallel suppression of insulin secretion and the combination of growth hormone and rhIGF-I may be more promising in this respect. ${ }^{1}$ The possible role of rhIGF-I as an adjunct to standard insulin treatment has been explored in adolescents with insulin dependent diabetes mellitus (IDDM).

\section{Abnormalities of the growth hormone/IGF-I axis in IDDM}

IGF-I concentrations are invariably low or in the low/normal range in adolescents with IDDM as are those of IGFBP-3.1819 Concentrations of both peptides are closely related to the insulin dose, and they increase during intensified insulin treatment. These observations are compatible with the known effects of insulin on the growth hormone receptor and GHBP concentrations are low in IDDM. ${ }^{18}$ Arslanian et al have shown that the introduction of insulin treatment leads to a prompt rise in GHBP but overall values are still lower in IDDM than those seen in normal subjects. ${ }^{20}$ Failure of standard insulin treatment to restore normal concentrations of GHBP and thus IGF-I appear to stem from the peripheral rather than direct portal vein administration of insulin. ${ }^{21}$

Overall IGF bioactivity is also markedly reduced in subjects with IDDM. ${ }^{22}$ This can, in part, be explained by the high concentrations of IGFBP-1. Fasting and overnight concentrations of IGFBP-1 are increased in adolescents with IDDM on standard insulin regimens, and the decrease in IGF bioactivity overnight is closely related to the rise in IGFBP-1.23 As with overall IGF-I concentrations, changes in bioactivity are closely related to the mode of insulin delivery. Brismar et al have recently shown that an increase in the portal levels of insulin leads to a prompt decrease in IGFBP-1 and an apparent increase in the bioavailability of IGF-I. ${ }^{24}$

Whereas the reductions in IGF-I and IGF bioactivity during puberty in IDDM are closely related to impaired growth, as yet there is no direct evidence that the reductions in IGF-I and increases in IGF-BP1 have direct effects on glucose disposal and insulin sensitivity in IDDM. Nevertheless there is good evidence that they may affect insulin sensitivity indirectly as they lead to growth hormone hypersecretion. Raised growth hormone concentrations in IDDM, particularly during puberty, are closely related to the development of insulin resistance and enhanced ketogenesis. ${ }^{21}$ Thus in short term studies restoration of normal IGF-I concentrations using rhIGF-I has been shown to lead to reductions in growth hormone hypersecretion and improvements in insulin sensitivity. ${ }^{25}$

\section{Does recombinant IGF-I have a therapeutic role in IDDM?}

Restoration of normal IGF-I levels using rhIGF-I could lead to reductions in insulin resistance by reducing growth hormone hypersecretion or by direct effects on insulin sensitivity. It has also been argued that it might also reduce raised glucagon concentrations in IDDM. ${ }^{15}$ Growth hormone hypersecretion, reduced IGF-I and raised IGFBP-1 values have been linked to poor glycaemic control as judged by glycated haemoglobin, particularly during puberty and thus clinical benefit might be expected.

Subcutaneous rhIGF-I administration in a dose of 40 $\mu \mathrm{g} / \mathrm{kg}$, equivalent to the estimated physiological production rate of IGF-I, leads to sustained increases of IGF-I concentrations in adolescents with IDDM which decline with a half life of around 20 hours. ${ }^{26} \mathrm{~A}$ rise in IGFBP-3 has also been observed ${ }^{26}$ and increased values of IGF-I are sustained over a period of 28 days despite reductions in growth hormone hypersecretion. Considerable improvements in insulin sensitivity have been observed during overnight and one month studies of rhIGF-I treatment. Thus preliminary data indicate that rhIGF-I may have a role in the treatment of IDDM particularly during puberty, but longer term studies are required to confirm this.

\section{Conclusions}

IGF-I and insulin share important structural similarities and receptor interactions. The regulation of IGF bioavailability by insulin provides an explanation for the nutritional regulation of growth and invokes the exciting hypothesis that IGF-I may also have a role in regulating short term changes in glucose and protein metabolism. If this were the case rhIGF-I treatment may be of benefit in catabolic states and IDDM where it might have effects on metabolism additional to those achieved indirectly by 
suppression of growth hormone concentrations. However, the fine line between the mitogenic and metabolic effects of IGF-I needs to be carefully defined. In IDDM it could be argued that reductions in growth hormone hypersecretion, insulin dose, and glycated haemoglobin brought about by rhIGF-I might lead to a reduced risk for microangiopathic complications, but in vitro evidence implicates tissue production of IGF-I in the development of these complications. Future studies will have to proceed cautiously, but the application of the effects of rhIGF-I, its analogues and the IGFBPs in the treatment of diabetes and catabolism will prove to be an exciting and innovative field of research.

Department of Paediatrics,

D B DUNGER

fohn Radcliffe Hospital,

Headington,

Oxford OX3 9DU

1 Bondy CA, Underwood LE, Clemmons DR, Guler HP, Bach MA, Skarulis M. Clinical uses of insulin-like growth factor-I. Ann Intern Med 1994; 120: 593-602.

2 Zapf J, Schoenle E, Froesch ER. Insulin-like growth factors-I and II, some biological actions and receptor binding characteristics of two purified conbiological actions and receptor binding characteristics of two purified constituents of non suppressible

3 Le Roith D, Sampson PC, Roberts CT. How does the mitogenic insulin-like growth factor-I receptor differ from the metabolic insulin receptor? Horm Res 1994; 41 (suppl 2): 74-9.

4 Ballard FJ, Baxter RC, Binoux M, et al. Report on the nomenclature of the IGF binding proteins. $\mathcal{F}$ Clin Endocrinol Metab 1992; 74: 1215-6.

5 Clemmons DR. IGF binding proteins: regulations of cellular actions. Growth Regul 1992; 2: 80-7.

6 Savage MO, Smith CP, Dunger DB, Gale EAM, Holly JMP, Preece MA Insulin and growth factors. Adaptation to normal puberty. Horm Res 1992; 37 (suppl 3): 70-3.

7 Amiel SA, Caprio S, Sherwin RS, Plewe G, Haymond MW, Tamborlan WV. Insulin resistance of puberty: a defect restricted to peripheral glucose metabolism. I Clin Endcrinol Metab 1991; 72: 277-82.

8 Hochberg Z, Hertz P, Colin V, Ish-Shalon S, Youdim MBH, Amil T. The distal axis of growth hormone in nutritional disorders: GH binding distal axis of growth hormone in nutritional disorders: GH binding protein, insulin-like growth factor-I (IGF-1) and IGF-1

9 Holly JMP, Biddlecombe RA, Dunger DB, et al. Circadian variation of $\mathrm{GH}$-independent IGF-binding protein in diabetes mellitus and its relationship to insulin. A new role for insulin? Clin Endocrinol (Oxf) 1988; 29, 667-75.

\section{Tuberous sclerosis}

Tuberous sclerosis is the commonest dominantly inherited condition causing epilepsy and mental handicap. It has attracted considerable research interest in the last decade and in this review we look at some of the new information on epidemiology, presentation, diagnosis, management, prognosis and genetics, relating clinical information to the discovery that the tuberous sclerosis genes are tumour suppressor genes.

\section{Epidemiology}

The clinical expression of tuberous sclerosis is so variable that the true prevalence of the disease remains unknown. Two observations suggest the birth incidence is considerably higher than previously estimated: (a) population based studies consistently identify a higher prevalence of the disease in childhood ${ }^{12}$ and (b) studies of children with the disease are particularly likely to be biased by under ascertainment of mildly affected cases. Because the prevalence of learning difficulties in tuberous sclerosis is now recognised to be lower than previously documented, ${ }^{34}$ we predicted the true birth incidence to be at least $1 / 6000 .^{3} \mathrm{~A}$ recent Swedish study found a prevalence of 1/6800 among children aged $11-15$ years. ${ }^{5}$
10 Holly JMP, Smith CP, Dunger DB, et al. The levels of the small MW IGF$I$ binding protein are strongly related to those of insulin in prepubertal and pubertal children but only weakly so after puberty. $\mathcal{F}$ Endocrinol $1989 ; 121$ : 383-7.

11 Lewitt MS, Denyer GS, Cooney GJ, Baxter RC. Insulin-like growth factor binding protein-I modulates blood glucose levels. Endocrinology 1991; 129: 2254-6.

12 Dimitriadis G, Parry-Billings M, Piva T, et al. Effects of insulin like growth factor I on the rates of glucose transport and utilisation in rat skeletal muscle in vitro. Biochem $\mathcal{F}$ 1992; 285: 269-74.

13 Guler HP, Zapf J, Froesch ER. Short term metabolic effects of recombinant human insulin-like growth factor I in healthy adults. $N$ Engl $\mathcal{F}$ Med 1987; 317: $137-40$.

14 Boulware SD, Tamborlane WV, Matthews LS, Sherwin RS. Diverse effects of insulin-like growth factor I on glucose lipid and amino acid metabolism. of insulin-like growth factor I on g

15 Sherwin RS, Borg WP, Boulware SD. Metabolic effects of insulin-like growth factor I in normal humans. Horm Res 1994; 41 (suppl 2): 97-102.

16 Quin JD, Fisher BM, Paterson KR, Inoue A, Beastall GH, MacCuish AC. Acute response to recombinant insulin-like growth factor $I$ in a patient with Mendenhall's syndrome [Letter]. $N$ Engl $\mathcal{H}$ Med 1990; 323: 1425-6.

17 Jabri N, Schalch DS, Schwartz SL, et al. Adverse effects of recombinant human insulin-like growth factor I in obese insulin resistant type II diabetic patients. Diabetes 1994; 43: 369-74.

18 Clayton KL, Holly JMP, Carlsson LMS, et al. Loss of the normal relationship between growth hormone, growth hormone binding protein and insulin like growth factor in adolescents with insulin dependent diabetes mellitus. Clin Endocrinol (Oxf) 1994; 41: 517-24.

19 Batch JA, Baxter RC, Werther G. Abnormal regulation of insulin-like growth factor binding proteins in adolescents with insulin-dependent diagrowth factor binding proteins in adolescents with
betes. $\mathcal{F}$ Clin Endocrinol Metab 1991; 73: 964-8.

20 Arslanian SA, Menon RK, Gierl AP, Heil BV, Foley Jr TP. Insulin therapy increases low plasma growth hormone binding protein in children with new onset type 1 diabetes. Diabetic Med 1993; 10: 833-8.

21 Dunger DB. Diabetes in puberty. Arch Dis Child 1992; 67: 569-70

22 Taylor AM, Dunger DB, Grant DB, Preece MA. Somatomedin-C IGF-I measured by radioimmunoassay and somatomedin bioactivity in adolescents with insulin dependent diabetes compared with puberty matched controls. Diabetes Res 1989; 9: 177-81.

23 Taylor AM, Dunger DB, Preece MA, et al. The growth hormone independent insulin-like growth factor-I binding protein BP-28 is associated with serum insulin-like orowth factor-I inhibitory bioactivity in adolescent insulin dependent diabetes. Clin Endocrinol (Oxf) 1990; 32: 229-39.

24 Brismar K, Fernqvist-Forbes E, Wahren J, Hall K. Effect of insulin on the hepatic production of insulin-like growth factor-binding protein-1 (IGFBP-1), IGFBP-3, and IGF-I in insulin-dependent diabetes. $\mathcal{f}$ Clin Endocrinol Metab 1994; 79: 872-8.

25 Cheetham TD, Jones J, Taylor AM, Holly JMP, Matthews DR, Dunger DB. The effects of recombinant insulin-like growth factor-I administration on The effects of recombinant insulin-like growth factor-I administration on
growth hormone levels and insulin requirements in adolescents with type I (insulin-dependent) diabetes mellitus. Diabetologia 1993; 36: 678-81.

26 Cheetham TD, Clayton KL, Taylor AM, Holly J, Matthews DR, Dunger DB. The effects of recombinant human insulin-like growth factor I (rhIGF-I) on growth hormone secretion in adolescents with insulin dependent diabetes mellitus. Clin Endocrinol (Oxf) 1994; 40: 515-22.

\section{Presentation}

The majority of individuals with tuberous sclerosis who present in childhood will have epileptic seizures and the disease should be considered in every child presenting with a seizure. Infantile spasms, complex partial and myoclonic seizures are the commonest seizures encountered. A significant number $(10 \%)$ of children presenting with infantile spasms will have tuberous sclerosis ${ }^{6}$ and the diagnosis is important as it will influence treatment (see below). Learning difficulties or autistic behaviour without seizures are rarely due to tuberous sclerosis.

A few children will present with skin lesions ${ }^{7}$ and other children will be seen because of the complications of cardiac rhabdomyomas ${ }^{8}$ or polycystic kidney disease. ${ }^{9}$ Cardiac rhabdomyomas cause their major problems in the perinatal and neonatal period and are associated with hydrops fetalis, heart failure, murmurs, arrhythmias, and Wolff-Parkinson-White syndrome. At least $80 \%$ of children presenting with cardiac rhabdomyomas will have tuberous sclerosis. ${ }^{8}$ The renal cystic disease of tuberous sclerosis is indistinguishable clinically from autosomal dominant polycystic kidney disease and usually presents in infancy with palpable abdominal masses, haematuria, and/or hypertension. The two conditions are thought to be 